\title{
The Politics of the Gilded Body in early Florentine Statuary
}

\author{
Alison Wright
}

The written history of Renaissance sculpture has encouraged us to see through gold surfaces. Attention trained to focus on the vehicle of 'form' can overlook gilding as skin deep. This is partly a consequence of the colour blindness of sculptural theory as it was developed in the later fifteenth and sixteenth century and of the way precious metalwork was excluded from a restricted definition of the arts of 'disegno'. When, in 1775, the painter Anton Raphael Mengs approached Tuscany's Grandduke for permission to remove brown varnish from the city's Baptistery doors to reveal their gilding, he was rebuffed on the grounds that the gold surface was too fragile and that 'even if the doors were of solid gold they would only be more beautiful to the eyes of the greedy, and more magnificent, but they would not satisfy a draughtsman/designer (disegnatore); just as an unpatinated bronze does not satisfy because of the false lights that confound one's sight' ${ }^{1}$ The disdain for gold

\footnotetext{
*I should like especially to thank the anonymous reviewers of this article for their critical reading and the precision they enabled. For their help, advice and hospitality while researching this paper I am very grateful to Kate Lowe, Peta Motture, Laura Jacobus, Stefania Giordano, Ludovica Nicolai, Patricia Rubin and Scott Nethersole.
}

${ }^{1}$ The response came from Raimondo Cocchi as Antiquario di Galleria: 'E quand'anche la porta fosse d'oro sodo, sarebbe più bella agli occhi degli avari e più magnifica, ma non 
as mere dazzle is at once moral and aesthetic. The tendency to see beyond the gilded surface is also an inevitable response to condition, since surface degradation from atmospheric pollution can undermine a gilded finish to a cast copper alloy. Though the gilding discerned by Mengs was in reality resilient and resurfaced fully again in 1947-8, the gold of the Baptistery doors had, for much of their six centuries in situ, been obscured beneath deposits of oxidised copper, dust and dirt, like that 'unswept stone besmear'd with sluttish time' of Shakespeare's sonnet LV. ${ }^{2}$

It has taken a series of spectacular campaigns of cleaning and conservation of Florentine gilded bronzes to restore some wonder at the effect of a nuanced and burnished gold sodisfarebbe un disegnatore; siccome non sodisfa un bronzo senza patina per i reflessi e i falsi lumi che confondo la vista'. He also refused on the mistaken grounds that the gilding was too fragile and incomplete. See G. Poggi, 'La ripulitura delle porte del Battistero fiorentino', Bollettino d'arte, 33, 1948, pp. 244-257 at pp. 249-250. Also cited by Annamaria Giusti, 'Patine e patinatura', in B. Paolozzi Strozzi (ed.), II ritorno d'Amore: L'Attis di Donatello restaurato, Museo Nazionale del Bargello, Florence, 2005. pp. 97-99; for the full letter G. Milanesi, 'A proposito della tintura delle porte di S. Giovanni', Arte e Storia, 4, 1885, pp. 217-221.

${ }^{2}$ See Poggi, ibid. for documented responses to the gilding from the fifteenth century to the 1940s; A. Giusti, 'Ghiberti's Gold: Restoration of the Gates of Paradise', in G. M. Radke (ed.), The Gates of Paradise: Lorenzo Ghiberti's Renaissance Masterpiece, (exh. cat.), High Museum of Art, Atlanta, 2007, pp. 99-109 at pp. 100-101. 
surface (fig. 1 ). ${ }^{3}$ Our own age is often in thrall to bright works, and dramatises the power to 'resurrect' decayed objects, but the cleaning of Ghiberti's two sets of doors for the Baptistery, gilded 1423-4 and 1452 respectively, has undoubtedly brought to the fore intentional effects, like the gleam of tooled armour or the flooding of the landscape with light, that the matt opacity of the working substitutes installed at the Baptistery cannot register. ${ }^{4}$ Driven by the need to stabilise their gold surfaces, the doors are now indefinitely preserved, as on a discrete life-support machine, in nitrogen-filled cases in the cathedral museum. Coeval with the gilding of the first doors was Donatello's completely gilded bronze St. Louis of Toulouse (finished c. 1425), which was most recently cleaned for exhibition with organic reagents. ${ }^{5}$ Of the city's large-scale gilded bronzes of this period, this leaves only the

3 A. Giusti (ed.), II Paradiso ritrovato: il restauro della Porta del Ghiberti, Florence, Mandragora, 2015.

${ }^{4}$ For the documents see R. Krautheimer, in collaboration with T. Krautheimer-Hess, Lorenzo Ghiberti, Princeton N.J, Princeton University Press, 1956, for the New Testament door p. 133, and p. 382, Dig. 101, Doc. 92 and, for the Old Testatment ('Paradise') doors p. 167, Dig. 282, Doc. 13 and Dig. 280, Doc. 47.

${ }^{5}$ While the doors were cleaned using lasers, the upright St. Louis was treated with Rochelle salts and agar agar gel, see B. Teodori and L. Nicolai, 'Donatello. San Ludovico di Tolosa, 1422-1425', Kermes, 25, no. 87, 2012, pp. 7-17. The exhibition was La primavera del Rinascimento at Palazzo Strozzi (its catalogue is hereafter cited in the English edition: B. 
recumbent effigy of Baldassare Cossa in the Baptistery in its original location where, until its restoration on site in 1986, it was scarcely recognisable as gilded. ${ }^{6}$ All appear now as unapologetically closer to goldsmiths' work, with yellow-toned, burnished surfaces, which, rather than simply ornamenting the figure, effectively transform it. The present study, by placing these ambitious sculptural works in relation to Florence's economy and especially its visual and political culture at a time of changing civic ethos, addresses the scope and limits of the gilded body. An approach from the history of the city offers a specificity that can enable more revealing comparative analysis ranging across Italy, and beyond. This is particularly important if we are to position and understand the choice for 'golden' and parcel-gilt works. While, for example, the figures of King Henry VII and Elizabeth of York on their tomb in Westminster Abbey were designed and cast by the Florentine Pietro Torrigiani, the workshop used local foundry skills, and the figures' reception drew on different sources

Paolozzi Strozzi and M. Bormand (eds), The Springtime of the Renaissance: Sculpture and the Arts in Florence, 1400-1460, (exh. cat.) Florence, Mandragora, 2013).

${ }^{6}$ See OPD Restauro, no. 3, 1988, pp. 121-124 and Archivio dell' Opificio delle Pietre Dure, Florence, G.R.N. 10021/I. Scheda di restauro 043556. Restored by Ludovica Nicolai and assistants using a solution of Rochelle salts. The cleaning showed the original gilding to be complete over $90 \%$ of the figure, as well as exposing the brown patination of the pall cloth. The gold ornament of the cushion, which proved to be a later mordant gilding, was removed. Annamaria Giusti commissioned further investigation of the effigy's surface condition in 2007. 
and meanings of gold metal. ${ }^{7}$ Their all-important dynastic claim depended on an existing tradition of fully-gilded effigies in England, showing living monarchs and princes in prayer, and on the distinction relative to the adjacent parcel-gilt effigy of Margaret Beaufort whose non-royal flesh was painted naturalistically. ${ }^{8}$ Such a context was completely lacking in Florence, a city in which the kind of permanent gilded funerary pomp that surrounded the Tudor effigies, and conditioned their reception, would have been unthinkable.

Whereas the semiotics of bronze sculpture in Florence from the late Middle Ages onwards has been frequently discussed, that of gilded bronzes has scarcely been touched on. ${ }^{9}$ This

\footnotetext{
${ }^{7}$ Leo von Rozmital, commenting on the 'twenty' gilded effigial tombs of London in 1465, linked them directly to the minting of gold nobles and silver coinage in the city (see Mrs. $\mathrm{H}$. Cust, Gentleman Errant: Being the Journeys and Adventures of Four Noblemen in Europe during the Fifteenth and Sixteenth Centuries, London, John Murray, 1909, p. 41). See recently for Torrigiano's English work and the casting of the first Tudor tomb A. P. Darr, 'Pietro Torrigiani and His Sculpture in Henrician England: Sources and Influences', C.M. Sicca and L.A. Waldman (eds), The Anglo-Florentine Renaissance: Art for the Early Tudors, New Haven and London, Yale University Press, 2012, pp. 49-80, esp. pp. 53-54; P. Motture, The Culture of Bronze: Making and Meaning in Italian Renaissance Sculpture, London, Victoria
} and Albert Museum, 2019, pp. 194-197.

${ }^{8}$ Darr, ibid., pp. 52-53; Motture, ibid., p. 195 and note 3, p. 251.

9 Richard Krautheimer (as at note 4 above, pp. 133-134) convincingly relates the gilding of the North Doors to the treasuring of goldsmiths work by contemporary elites; M. Collareta, 
may be because gold on statuary can be difficult to read and not just to see, depending as it does on questions of location, audiences with different knowledge and expectations and changes in both attitude and material surfaces over time. By probing the relationship between the material and aesthetic character of these works and a specific early fifteenthcentury moment in Florentine civic life we gain a better understanding of just what such fully-gilded bodies were symptomatic, and of why their exceptional visual effects were not repeated in large-scale public statuary after the 1420 s.

\section{Gilding with fire}

The process by which a copper alloy or silver surface was turned to gold was, literally and metaphorically, mercurial. Its alchemical fascination and transformative character are expressed by the Sienese founder, Vannoccio Biringucci, in terms of deceit: 'Except for the

'L'ultima età dell'oro', in Bagliori dorati. I/ Gotico internazionale a Firenze, 1375-1440, Florence, Giunti, 2012, p. 63-69 addresses more generally the 'arts of fire'; P. Sénéchal, 'The Bronze Casting Challenge', in Paolozzi Strozzi and Bormand (eds) as at note 5 above, and esp. pp. 103-109 at pp. 104-5; M. Collareta, ‘Oreficeria e scultura nell’arte fiorentina del Quattrocento', in ibid. pp. 97-101 at pp. 98-9. Important contributions are E. Lein, Ars aeraria: die Kunst der Bronzegiessens und de Bedeutung von Bronze in der florentinischen Renaissance, Mainz am Rhein, Philipp von Zabern, 2004, pp. 58-66; M. G. Vaccari, 'Donatello e l'oro' in B. Paolozzi Strozzi (ed.), Donatello. Il David restaurato, Florence, Giunti, 2008, pp. 106-119; L. Goldenbaum, In testimonium veritatis: Der Bronzegisant als Totenabbild im italienischen Quattrocento, Berlin, Deutscher Kunstverlag, 2018, Chap. 4.2 and Motture, ibid. esp. p. 68. 
manual work, the art of the goldsmith has a close connection with that of the alchemists because it often makes a thing appear what it is not, as is seen in $[\ldots]$ in heightening the colour of gold, in whitening silver, and also in gilding things that really are of silver, brass, or copper, but appear to be of gold [...]'. ${ }^{10} \mathrm{His}$ De la Pirotechnia (1540) goes on to describe two methods of transformation: in the first, gold leaf is attached to the object that has been 'enlivened' (quickened) with mercury, in the second, fine gold is mixed with mercury, heated to an amalgam (Theophilus and Benvenuto Cellini describe a ratio of 1:8) and spread on to the prepared metal with a copper rod and brush. ${ }^{11}$ The mercury is then evaporated in the furnace leaving behind the gold 'which is quenched in urine...' The technique of bonding gold onto copper and its alloys, or to silver, was of great antiquity but the twelfth-century

${ }^{10}$ Vannoccio Biringucci, De la Pirotechnia, Venice 1540, (Book IX, chapter 4) (see C. S. Smith and M. T. Gnudi, transl. MIT Press, Cambridge Mass. 1943, p. 367). For methods of gilding, evidence of fire-gilding, and its durability, see A. Oddy, 'A History of Gilding with Particular Reference to Statuary' in T. Drayman-Weisser (ed.), Gilded Metals: History, Technology and Conservation, London, Archetype Publications, 2000, pp. 1-19 with extensive bibliography; Motture, as at note 7 above, p. 68.

${ }^{11}$ Biringucci's is an image of animation: '[...] con argento vivo inviviando la cosa'. See, for the Italian text and other sources for the gilding of bronze, Lein at note 9 above, pp. 58-62. Mercury gilding, requires an alloy substrate high in copper and low in lead. For the wide variation in copper alloys used for sculpture and their different qualities see esp. Motture, as at note 7 above, pp. 18-25. 
account by Theophilus offers the most extensive description of the goldsmiths' method of fire gilding, emphasising the care needed in spreading the cleaned gold-mercury amalgam evenly (with a hog's hair brush), and repeatedly, heating between applications and rubbing with a brush until the yellow of the gold appeared. ${ }^{12}$ Burnishing was to be done with copper wire scratch-brushing - cleaning in between sessions - until the work 'takes on a brilliant lustre'.$^{13}$ For Cellini, fire-gilding is a 'beautiful and marvellous craft' that should be mastered in order to guide others. ${ }^{14}$ But whereas Theophilus merely recommended firegilding on a full stomach to avoid sickness, Cellini saw it as a specialist labour that was unfit for master sculptors 'who ought not to practice it themselves, for that quicksilver that has to be used for it is a deadly poison, and so wears out the men that practise in that they live but a few years'. The toxic labour of the artisan at the point of gold's deposit has a chilling

12 Theophilus, De diversis artibus, Chaps 35-38 and 68, see J. G. Hawthorne and C.S. Smith (ed and transl), Theophilus On Divers Arts. The Foremost Medieval Treatise on Painting, Glassworking and Metalwork, New York, Dover Publications, 1963, pp. 110- 114 and pp. $145-6$.

13 Theophilus, ibid., p. 114 (Chap 39). Like Cellini, Theophilus (Chap 40) also has a recipe for enhancing the colour of the gilding after burnishing. For preparing the amalgam, pp. 108114 (Chaps 35-37).

14 B. Cellini, Due trattati, Florence 1568, Chap 25 (The Treatises of Benvenuto Cellini on Goldsmithing and Sculpture, transl. C.R. Ashbee, Dover Publications Inc., New York, p. 95). 
symmetry here with the sacrifice of modern day artisanal gold miners, whose exposure to mercury-based methods of extraction damages their nervous system. ${ }^{15}$

That gilding bronze did not need to be directed by the designer/sculptor is affirmed at an early moment in Florence when the Board of Works or Opera of the Baptistery decided that Ghiberti's competition relief of the 'Story of Abraham' (1401) should be gilded 'to test various masters and choose the best one' ${ }^{16}$ Ghiberti was himself a goldsmith but the Opera reserved its right to judge who would gild his work. Some twenty years later, when the first doors were due for installation, the Board had to return to the decision to apply gold and their hesitation was certainly financial. Gilding, though a supplement to an already perfected bronze, added massively to the total material expenditure by the commissioner, and the frequent implication in the scholarship that gilding was the designer's choice must

${ }^{15} \mathrm{H}$. Gibb and K. G. O'Leary, 'Mercury exposure and health impacts among individuals in the artisanal and small-scale gold mining community: a comprehensive review', Environmental Health Perspectives, 122, 2014, pp. 667-672 accessed

online 1.12.2019: https://www.ncbi.nlm.nih.gov/pubmed/24682486

${ }^{16}$ Krautheimer, as at note 4 above, p. 370, Dig. 6 Doc. 33: 'Dorassi il Compasso della Storia d'Abramo del testam[ent]o vecchio per fare prova di diversi Maestri e pigliare che meglio facesse'. This decision leaves the interesting proposition that either the surviving relief has been selectively gilded by different hands or that the other bronze competition reliefs were all to be gilded (as Brunelleschi's certainly was). 
always be questioned. ${ }^{17}$ The Cloth Guild's decision to gild at all costs, is stated unequivocally as 'for honour and fame', showing that the city's reputation and their own was at stake. ${ }^{18}$

The desire to accrue 'honour and fame' was a fundamental driver for all commissions for public statuary in this period. But if Trexler was right to suggest a perceived deficit of legitimacy in mercantile Florence relative to princely states, then gilded works could represent a way to proclaim honour through its capacity to invoke a sovereign authority. ${ }^{19}$ The European association of the gilded body with this authority was, at a general level, manifested in gold or gilded regalia or armour enhancing the aura of the princely body, and in images of the ruler struck on gold coinage. ${ }^{20} \mathrm{~A}$ deliberation of the Opera del Duomo

17 The cost of the gold alone for the 'Paradise' doors was over 884 gold florins, see Krautheimer, ibid. p. 372, Dig. 280, Doc. 47.

${ }^{18}$ Krautheimer, ibid., p. 133 and p. 382, Dig. 101, Doc. 92, 'Quod erat magis considerandum et extimandum honor et fama quam expensa et ideo (?) ipsa doretur'. The bronze reliefs of the Siena Baptistery font, well advanced by 1423 , and always considered for full gilding, were probably the immediate challenge to Florentine honour.

19 R. Trexler, Public Life in Renaissance Florence, New York, Academic Press, 1980, esp. pp. 17-27, 279-281 for this broad-brush claim.

${ }^{20}$ The sovereign, quasi-sacred, authority of the Holy Roman Emperor was manifest in his golden pluvial and stole, as well as the gold imperial crown and orb that signalled delegated 
concluded that the sandstone lion installed on the staircase of the papal apartment at S. Maria Novella should be enhanced with gilding on the occasion of the Florentine visit of Pope Eugenius IV in 1435. The stated aim of this doratura of a civic emblem was for 'the honour of the Commune of Florence', not that of the pope. ${ }^{21}$ While the latter might read the honour to himself as mirrored by this gleaming figure, its lustre emanated from city. ${ }^{22}$

\section{Ancient gold?}

On the rare occasions where entirely gilded surfaces of sculpture are referred to in the secondary literature on Florentine fifteenth-century art, the most common move has been to anchor them in a desire, whether by makers or patrons, to invoke ancient Roman

authority from God (an all-gold Charlemagne appears in this regalia enthroned on the sceptre of King Charles V of France of 1380). Gold coinage was clearly used to assert governmental authority when gold nobles were minted by Edward III of England within the territory of Aquitaine (P. Spufford, Power and Profit: The Merchant in Medieval Europe, London, Thames and Hudson, 2002, p.14).

${ }^{21}$ The lion, carved by Donatello and now in the Bargello, Florence, was commissioned for the visit of Eugenius' predecessor, Martin V, in 1419.

${ }^{22}$ Archivio dell'Opera di Santa Maria del Fiore, II, 2, 1 f. 234 'Deliberazioni' 17 May 1435: 'Item deliberaverunt quod leo qui est super angulo schale habitationis pape eugenii in Sancta Maria Novella expensis Opere auretur pro honorantia Communis Florentie'. http://duomo.mpiwg-berlin.mpg.de/ITA/HTML/S021/C438/T004/TBLOCK00.HTM Accessed 27.11.19. 
statuary. ${ }^{23}$ At first inspection this seems fully justified given the weight of ancient precedent in so many aspects of Florentine civic discourse, humanistic thought and in Tuscan sculpture of this period, with scholars like Leonardo Bruni (Chancellor of Florence 1410-11 and 14271444) part of the debate over public sculpture..$^{24}$ But a default reference to Greek or Roman practice requires scrutiny. The gold or fully-gilded statuary of antiquity was known as much from ancient texts as from surviving works. ${ }^{25}$ Though the damaged 'Regisole' or 'Sun King'

${ }^{23}$ For example, Collareta as at note 9 above, pp. 67-68; Sénéchal, as at note 9 above, p. 105; Greenhalgh, Donatello and his Sources, New York, Holmes \& Meier, 1982, p. 73; Diane Zervas (The Parte Guelfa, Brunelleschi and Donatello, New York, J.J. Alexander, 1987, pp. 137-8) takes a more nuanced approach. Robert Lightbown (Donatello and Michelozzo: an Artistic Partnership and its Patrons in Early Renaissance Florence, London, Harvey Miller, 1980, I, p. 43) argues that expenditure on so much gold for the Cossa effigy suggests the executors were seeking a work in gilded metal rather than antique bronze.

${ }^{24}$ Bruni famously provided a (rejected) programme for the second set of Baptistery doors. His 'civic humanism' offered an ideological underpinning for public projects like the Parte Guelfa niche (see Zervas, ibid. pp. 9, 13-14, 47-50, 56-60).

${ }^{25}$ The two principle sources were Pliny the Elder's, Historia Naturalis, and Pausanias' Description of Greece (of which Niccolo Niccolì owned a copy by 1418), see further below at notes 31, 33 and 34. Vitruvius (De architectura, Book 3, Chap. 3, 5) refers to terracotta or gilded bronze statues decorating the pediments of temples 'in the Tuscan manner'. For knowledge of ancient statuary in the early fifteenth century see, for example, A. Cavallaro and E. Parlato (eds), Da Pisanello alla nascita dei Musei capitolini: l'antico a Roma alla vigilia 
horseman was remade and re-gilded in Pavia in the Trecento, the gilded equestrian statue outside the papal palace at St. John Lateran or the related colossal bronze fragments could, after centuries of exposure and maltreatment, hardly have been shining witnesses to the practice of antique gilding. ${ }^{26}$ Contemporary Florentine sources do not mention gold nor are comparable bronzes represented in these terms. Uccello's equestrian fresco of John Hawkwood all'antica (1436) for example, employs the pale green tones that give the monument the hue of oxidised copper, while Ghiberti's Commentaries (1447/8 - 1455),

del Rinascimento, exh. cat., Milan, A. Mondadori and Rome, DeLuca, 1988; S. B. McHam, Pliny and the Artistic Culture of the Italian Renaissance: The Legacy of the Natural History, New Haven and London, Yale University Press, 2013, Chap. 7 and pp. 133-134; N. Gramaccini, ‘Die Umwertung der Antike - Zur Rezeption des Marc Aurel in Mittelalter und Renaissance', in Natur un Antike in der Renaissance, exh. cat. Liebighaus, Frankfurt an Main, 1986, pp. 51-83; W. J. Wegener, "That the practice of arms is most excellent declare the statues of ancient men': the Lucan War and Florentine Political Ideology in Paintings by Uccello and Castagno', Renaissance Studies, 7, 2, 1993, pp. 129-167 at pp. 153-5. For the question of whether Ghiberti had seen ancient sculpture with silvered eyes see Lein, as at note 9 above, p. 63.

${ }^{26}$ For the equestrian Regisole 'idol' see C. Saletti, Il Regisole di Pavia, Como, New Press, 1997, esp. pp. 32-38 and recently Motture, as at note 7 above, p. 82. 
which discusses ancient sculpture at length, mention no gilding on any ancient bronze works, including those he encountered in Rome. ${ }^{27}$

That Ghiberti should also fail to refer to the honorific gilding of his own reliefs in his autobiographical sketch seems especially remarkable. But should we be surprised at his silence? His writings on optics show his analytical sensitivity to incident and accidental effects of light (lume) on different materials. ${ }^{28}$ But writings on art of this period have little to say about the effects of gold in sculpture in any context. Filarete refers to the gilding of the bronze doors and architectural members inside his ideal temple and, in describing the setting of a commemorative obelisk to an ancient King Zogalia (entrusted to a dream team of Donatello, Desiderio da Settignano and the goldsmith/medallist Cristoforo di Geremia),

27 Lorenzo Ghiberti, I Commentarii, L. Bartoli (ed.), Florence, Giunti, 1998, p. 3 refers to pure gold statues as the earliest ancient works. As bronze fragments of what he believed to be Zenodorus' colossus of Nero, Ghiberti may have suspected the giant head and hand at the Lateran were once gilded (ibid. p. 58).

${ }^{28}$ He even notes the phenomenon of concentrated sunlight or its reflection producing temporary 'golden' vision, Ghiberti, ibid. section 3, pp. 100-108; A. R. Bloch, Lorenzo Ghiberti's Gates of Paradise: Humanism, History and Artistic Philosophy in the Italian Renaissance, Cambridge, Cambridge University Press, 2015, p. 6. 
he has his patron request that the supporting bronze lions should be gilded. ${ }^{29}$ Leon Battista Alberti, whose architectural treatise was more closely modelled on ancient precedent, voices doubt as to the proper materials for cult statuary before insisting on thin-walled bronze. ${ }^{30}$ Gold, the 'prince' of metals might, he says, be appropriate to the figure of the deity, but it offered temptation to sin by inviting theft and melting down. It also had the unfortunate tendency to draw admiration to itself, deflecting that owed to craftsmanship (a material aesthetic critique to which he gives a slightly different inflection in his treatise on painting). Ghiberti, like Alberti, was a keen reader of Pliny the Elder's Natural History, whose Book 33, dedicated to metals, famously denigrates gold as a sculptural medium, principally on moral grounds. While acknowledging the much coveted 'Corinthian bronze', its copper alloyed with silver, gold, or both metals, Pliny launched a scathing attack on gilded surfaces on statuary. ${ }^{31}$ Gold was seductive, inducing covetousness and stimulating the excesses of the Roman triumph, while love of luxurious plate, engraved with erotic scenes fed the destruction of statues to realise their precious metals. Ghiberti surely did not share Pliny's moral repulsion for the gilded figure; certainly he lamented the destruction of ancient

${ }^{29}$ Filarete, Libro architettonico, 1464, Book 9, f. 65v and Book 14, f. 102v (see Antonio Averlino detto il Filarete, Trattato di Architettura, (eds) A. M. Finoli and L. Grassi, Milan, II Polifilo, 1972, II, pp. 252 and p. 390).

${ }^{30}$ L. B. Alberti, De re aedificatoria, pub. 1485, Book 7, Chap. 17, (see L'architettura (De re aedificatoria), G. Orlandi and P. Portoghesi (eds), II, Milan, II Polifilo, 1966, pp. 661-663).

31 Pliny the Elder, Natural History, Book 33, 1-150. 
images in the Commentarii. But he was evidently aware of the ancient author's attack since he recounts the anecdote from Pliny's life of the sculptor Lyssipos concerning the bronze portrait of the young Alexander, a work that its later Roman owner, Nero, ordered to have covered in gold. ${ }^{32}$ Pliny continues: 'Then as this costly addition spoiled the work, the gold was removed and the statue was considered more valuable without it, despite the scars upon it and the incisions for fixing the gold'. ${ }^{33}$ The story of the stripping of gold to restore the beauty of the Greek bronze (as an excess tastelessly imposed by a decadent emperor) underlines that the aesthetics of the gold surface cannot be separated from its politics.

A gilded bronze figure communicates quite differently from a narrative relief in the same materials. An historiated scene justifies gilding by referring the honorific supplement of gold to an honourable event. The gilded statue instead elevates an individual in a way that renders the figure superhuman. Ancient written sources suggested that gold or gilding in antiquity was rare before the imperial Roman era, and generally reserved for the bodies of gods, deified or triumphant rulers and symbolic animals. ${ }^{34} \mathrm{~A}$ similar distinction was

32 Ghiberti, as at note 19 above, p. 61.

33 Pliny the Elder, as at note 31 above, Book 34, 63. See The Elder Pliny's Chapters on the History of Art, (transl. K. Jex-Blake), Chicago, Argonaut Inc., 1968, p. 51.

34 The most famous were the colossal, gold-laminated ivory and wood cult statues by Phidias at Athens and Olympia, with their attendant animals, but Pausanias describes gilded bronze statues in other parts of Greece, such as the Apollo ascribed to Chirisophus in the 
preserved in Quattrocento representation, though angels and saints, who mediated with the heavenly realm, could also be represented fully golden as part of larger gold or gilded objects. Certainly, without the abstraction attendant on deification or allegory no fullygilded female figures would have been produced in Quattrocento Tuscany. Biblical heroines framing the reliefs of the 'Paradise doors' are given fully gilded bodies, but then so are their accompanying ornaments; in the indiscriminate gilding of the relief fields, Eve herself gains the same honour. The eloquent gilded Virtues on the Siena font (c. 1427-29) and numerous ephemeral golden figures, made for occasions such as entries and feasts, testify to the more general sublimation from actual women such gilding assumed.

\section{Florentine gold}

Before the development of the myth of a Medici 'golden age', the politics of gold sculpture in Florence was closely related to its republican ethos. Circa 1400, the only statue known to have been fully gilded in Florence was the life-size stone lion or 'Marzocco', seated at the corner of the prior's rostrum, where it served as a symbolic guardian of the sovereignty of

temple at Tegea (Description of Greece, Book 8, Chap 53, 8). Most unusual is the gilded bronze statue by Praxiteles of the beautiful prostitute Phryne, consecrated in the temple at Delphi (Description of Greece, Book 10, Chap 15, 1). See also C. Mattusch, Classical Bronzes: The Art and Craft of Greek and Roman Statuary, Ithaca and London, Cornell University Press, 1996, pp. 28-29. 
the government (fig. 2). ${ }^{35}$ As an emblematic beast its gilding was quite uncontroversial. That completely gilded human figures should have been a feature of Florentine bronze production in the early years of the fifteenth century is remarkable, even in an era of such technical ambition and conceptual experimentation. Gilded statues are ambivalent figures in as much as they are not just ornamented in gold but have a golden skin. In the medieval period and beyond they were a by-word for idols and usually represented twinned with high columns (fig. 3). Gold places them definitively beyond their immediate visual environment, rendering them god-like and in certain circumstances, uncanny. Even as they become hypervisible through the light-catching and reflective properties of a yellow-toned, polished surface, their legibility becomes less assured. Such abstraction produces an instability that affects not just the visual contours of the figure but the contours of their meaning.

Whereas gold offered to God was acceptable, goldness in the wrong place or attached to the wrong person was excessive in other respects than financial. Apart from sanctioned occasions, gold adornment of dress or jewels on the body of the Florentine citizen was strenuously curbed by sumptuary law and could be equated with civic decadence. ${ }^{36} \mathrm{~A}$ crucial

\footnotetext{
${ }^{35}$ For its Guelf, symbolic and ritual significance see B. Cassidy, Politics, Civic Ideals, and Sculpture in Italy, c. 1240-1400. Turnhout, Brepols, 2007, pp. 224-8, referring also to the gilded lions commissioned for the portal of the Palazzo della Signoria in 1340.
}

36 D. O. Hughes, 'Sumptuary Laws and Social Relations in Renaissance Italy', in J. Bossy (ed.), Disputes and Settlements, Law and Human Relations in the West, Cambridge, Cambridge University Press, 1983, pp. 84-9 and 96-99; C. C. Frick, Dressing Renaissance Florence. 
factor in the genesis of gilded statuary in the republic of the 1420s was not simply the excuse of 'foreign' subjects to whom it might be applied, but gold's position within the thriving economy of the early years of the century. Gold was available in the city in unusual abundance. A highly favourable trade balance by which large-scale exports of Florentine goods were paid for in precious metal currency led to a massive net flow of the metal into the city and, with it, came the capacity for minting gold and silver coinage in great quantity. ${ }^{37}$ Though the supply of gold and silver was unreliable, from the mid thirteenth century to the later fifteenth, the Florentine gold florin served as a stable circulating currency, a money of account, and a standard in international trade. In what Goldthwaite terms the 'era of the florin', the city prided itself on large-scale transactions in gold and the coin was also preferred by the papacy for its revenues. The quasi sacred authority of the coinage, stamped with the image of St. John the Baptist, and its relevance for the Cloth Guild, which also elected the governors of the Mint, is even marked on the reverse of the 'Paradise' doors of the Baptistery commissioned by the guild. The images impressed by punching tools used to compile the dies for the coinage, show John the Baptist and the

Families, Fortune and Fine Clothing, Baltimore and London, Johns Hopkins University Press, 2002, pp. 180-190.

${ }^{37}$ R. A. Goldthwaite, The Economy of Renaissance Florence, Baltimore, Johns Hopkins University Press, 2009, pp. 48-52, noting the plentiful supply of gold in the local market, of precious metal coinage from mint, and of 'sealed' florins, and pp. 61-3 for the varied evidence for gold coming into Florence even after the precious metal 'famine' of the 1460s. 
Florentine lily, and appear stamped into the bronze alongside the arms of the governors of the mint for the period of $1448-9$ as they appeared on the florin. The function of these tiny traces is not certain, though they might have been used to assess the merits of designs by the die cutters Michelozzo di Bartolommeo and his successor Bernardo Cennini. Whatever the case, their application before the gilding of the reliefs confirms the tight relationship between Florentine metalworking skills and commerce, as well as that between civic bronze and Florentine gold. ${ }^{38}$

The florin was one of several gold currencies preferred for business transactions and had to adapt to changing patterns of production and trade in and beyond Europe. Just as 'sealed florins' stopped circulating as specie, the patrician Giovanni Rucellai recorded Florence' new galley trade with the Levant and the minting of new broader florins, the 'fiorini larghi di ghalea' to compete with the Venetian ducat. ${ }^{39}$ Tellingly, Rucellai notes directly after this, in the same year 1422, the introduction of the manufacture of gold thread into the Florentine silk industry, 'which it was not known how to do before'. ${ }^{40}$ The link is drawn directly between the availability of gold and the adoption of the specialist technology of beating gold and silver, strip cutting and wrapping silk thread required to make silk brocade 'cloth of

${ }^{38}$ D. L. Bemporad, 'Nel cantiere di Ghiberti. Un concorso singolare', in T. G. Verdon (ed.), La porta d'oro del Ghiberti, Florence, Mandragora, 2014, pp. 65-73.

39 'Il Zibaldone Quaresimale', 1422, in A. Perosa (ed.), Giovanni Rucellai e il suo Zibaldone, I, London, The Warburg Institute, University of London, 1960, p. 45.

40 lbid. I, p. 46 and 62. 
gold'. ${ }^{41}$ Goldsmiths and goldbeaters (battiloro) were both at the top of the hierarchy of members of the Arte della Seta, or Silk Guild, who regulated this prestigious and developing sector of Florentine production. This was a period of great prosperity for those in the silk trade and in banking, but the economy as a whole was weak and the interests of 'minor' guildsmen continued to lose out in government to members of the major guilds. These were high-end manufacturers, merchants, bankers and, predominantly, members of the propapal Parte Guelfa, a city-wide, communal and private body that strongly consolidated oligarchic and aristocratic interests in the communal regime. ${ }^{42}$ Following the Ciompi Revolt

${ }^{41}$ Goldthwaite, at note 37 above, p. 325, for the setting up of a partnership in the early 1420 s by three silk workers to produce beaten gold for the manufacture of cloth of gold; this involved attracting practitioners from Genoa and Venice. B. Dini, 'Una manifattura di battiloro nel quattrocento', in Tecnica e società nell'Italia dei secoli XII-XVI, Pistoia, Editografica, 1987, pp. 83-111. For goldbeaters in Florence see K. Prajda, 'Goldsmiths, goldbeaters and other gold workers in early Renaissance Florence 1378-1434', in E. Julien et al (eds), Vierteljahrschrift für Sozial- und Wirtschaftsgeschichte, 238, 2016, pp. 197-221 and in Italy see G. Pignolo, Effetti d'oro. Storia e tecnica dell'adoratura nell'arte, Editrice Compositori, Bologna, 2000, pp. 25-30.

42 Zervas, as at note 23 esp. Chapter 2; Cassidy, as at note 35 above, Chap. 5 for the longer history of Guelf - Ghibelline rivalry as it effected monumental sculpture. For the wealth gap between the tiny percentage of the super rich and the fiscal poverty of $82 \%$ of Florentine citizens revealed in the 1427 Catasto returns see G. Brucker, The Civic World of Early 
by textile workers, the Guelfs sought to re-establish their authority, entering into a lengthy power struggle that saw the defeat of the 'guild government' by the early 1400 s.

\section{St. Louis of Toulouse}

The expression of a gold-rich economy in search of nobility surfaces on the Parte Guelfa's statue at the guild church of Orsanmichele. Their aristocratic and golden St. Louis of Toulouse, produced by Donatello with his partner Michelozzo and completed in 1425, formed a deposit of honour in an account that was civic and political as much as spiritual. ${ }^{43}$ The gold leaf alone would have cost well in excess of 400 florins. ${ }^{44}$ Although there is no supporting record, the Major guilds seem to have had a special dispensation from the commune to commission in bronze and, already in 1419, the Banker's Guild had considered complete gilding for Ghiberti's St. Matthew. ${ }^{45}$ The bronze St. Stephen, commissioned by the Renaissance Florence, Princeton NJ, Princeton University Press, 1977, Chap 6, esp. p. 401 and 403 .

${ }^{43}$ Zervas, as at note 23 above, pp. 111 and 114, for a date between c. 1420 and November 1425 , when the Parte initiated the first honouring of the saint's feast at Orsanmichele.

${ }^{44}$ Zerva, ibid., p. 368, with summarised figures for early Quattrocento Florentine bronze and gilding costs at pp. 366-8.

${ }^{45}$ Ghiberti's contract of 1419 states explicitly that he was to 'to gild all or part of it according to the wishes of the operai and consuls', Krautheimer as at note 4 above, Dig. 71 ; Zervas, ibid., p. 118. For Ghiberti's approach, using a brass alloy and local mordant gilding see E. 
Wool Guild in 1425, may also have been a candidate for full gilding, but the surviving painted design for what is almost certainly Ghiberti's tabernacle ensemble shows it ungilded, with marginal gold ornaments over a luminous pale bronze (fig. 4). ${ }^{46}$ In the event, the St. Louis statue alone was fully gilded, holding sway over its rivals for finish as well as its exceptional height and weight, even before one acknowledges the importance of the classicising tabernacle in which it was placed. ${ }^{47}$

Luciano, 'A More 'Modern' Ghiberti: The St. Matthew for Orsanmichele', in C. B. Strehlke (ed.), Orsanmichele and the History and Preservation of the Civic Monument, New Haven and London, Yale University Press, pp. 213-242. The 1406 communal directive, which obliged the guilds to expedite the decoration of their allotted piers at Orsanmichele or risk losing their rights over them, mentions only marble statuary (G. Gaye, Carteggio inedito d'artisti dei secoli XIV-XVII, I, Florence, G. Mollini, 1839, pp. 542-543; retranscribed in Zervas, as at note 23 above, Appendix IV, A, no. 2). My thanks to an anonymous reader for correcting me, and a common misconception in the scholarship.

${ }^{46}$ See Krautheimer, as at note 4 above pp. 93-100, and Docs. 107-113 for the commission of the statue; pp. 97-99 for the drawing; Lein, as at note 9 above, pp. 58-9. Dominique Cordellier (in Paolozzi Strozzi and Bormand (eds) as at note 5 above, III.17 pp. 320-321), expresses scepticism about the drawing's relation to the St. Stephen, but see also Davide Gasparotto in M. W. Cole ed., Donatello, Michelangelo, Cellini: Sculptor's Drawings from Renaissance Italy, Isabella Stewart Gardner Museum, Boston and Paul Holberton Publishing, London 2014, p. 41. 
St. Louis of Toulouse was removed to S. Croce already before 1460, and it was only in 1943 that the statue's fit with what had been the Parte's niche was re-established (fig. 5 shows it as a haunting revenant there during that brief reappearance). Bruno Bearzi's exemplary postwar cleaning and analysis of the statue went on to reveal generally well-preserved gold beneath the copper green. ${ }^{48}$ The marble frame effectively affirmed the emanating light from the gilded statue, by its own partial gilding and through the coincidence of the upturned conch shell with the saint's head, producing a radiating halo. This is nonetheless a union of opposites, for the appearance of the sculpture is the reverse of antique. It is conceived as a summa of liturgical drapery moulded in high relief, topped by a head with a separately cast and enamelled mitre. Ingeniously fashioned in eleven sections, these were slotted or bolted together by an assembly method that recalls that of goldsmith's works and that, crucially, allowed for full gilding of smaller parts before assembly. ${ }^{49}$ There is no body per se. Yet the convincing sway and crumple of the cope affirms the expressive conceit that here is a very young man inhabiting an older man's mantle.

47 Zervas, as at note 23 above, pp. 138-153.

${ }^{48}$ B. Bearzi, 'Considerazioni di tecnica sul San Ludovico e la Giuditta di Donatello', Bollettino d'Arte, 35, 1951, pp. 119-123 (republished by L. Dolcini, Donatello e il restauro della Giuditta, Florence 1988, pp. 64-66); Bearzi, 'La tecnica fusoria di Donatello', in Donatello e il suo tempo, Florence, Istituto Nazionale di Studi sul Rinascimento, 1968, pp. 97-105.

${ }^{49}$ Teodori and Nicolai, as at note 5 above, pp. 8-10. 
Kristen Van Ausdall and David Boffa have rightly insisted on the essential relationship between figure and tabernacle for understanding both the sculpture's conception and its function as a cult figure. ${ }^{50}$ Drawing on St. Louis's Vita, Boffa argued that the saint is shown at a specific moment, appearing to his devotees above his own funerary altar in episcopal robes, blessing the people. ${ }^{51}$ For Donatello's sculpture to have its effect, however, the viewer does not need to know the posthumous miracle. Rather, I would suggest, this hagiography offers an explanation for how the sculpture might operate in relation to devotees or passing viewers. The gilding that extends across the whole of the young figure intimates a heavenly glory in the here and now, as of some giant angel appearing. The materiality of its gold on bronze registers in relation to its cult function as something immaterial and transcendent, a feature of the saint in glory that also indicates ontological

50 K. Van Ausdall, 'The Corpus Verum: Orsanmichele, Tabernacles, and Verrocchio's Incredulity of St. Thomas', in S. Bule, A. Phipps Darr and F. Superbi Gioffredi (eds), Andrea Verrocchio and Late Quattrocento Florentine Sculpture, Florence, Le Lettere, 1992, pp. 3339; D. Boffa, 'Divine Illumination and the Portrayal of the Miraculous in Donatello's St. Louis of Toulouse', Simiolus: Netherlands Quarterly for the History of Art, 31, no. 4, 2004-2005, pp. 279-291.

${ }^{51}$ Bartolommeo da Pisa, 'De conformitate vitae Beati Francisci ad vitam Domini lesu' published in Analecta Franciscana, 4, Frati Editori di Quaracchi, 1906, pp. 309-31, at p. 316. 
separation..$^{52}$ One might still imagine a somewhat uneasy status for such a figure at the feast day in August, when the golden saint was the focus of Guelf Party and communal devotion. Aligned with, but also contrasted to, the naked bodies of the shield-bearing spiritelli on the crozier (likewise standing in niches) the saint deflects idolatry mainly by his voluminous dress: a more ecclesiastically armoured body than his would be hard to imagine.

Though scarcely a model for Florentine giovani, for whom the Parte Guelfa sponsored civic displays of arms, it is important too that Louis of Anjou was a noble youth and not a king. He had been expected to take on the splendid body of the ruler but chose to pass the crown of Naples to his brother in order to embrace Franciscanism. Appointed Bishop of Toulouse at twenty two and just twenty three when he died, Louis is depicted by Donatello with what seem even younger features and these sit in touching tension with the oversized character of his regalia (fig. 6). His head supports a mitre set with rock crystals and Angevin lilies, gold on blue, his hands are encased in heavy gloves and the body enveloped, his bare 'Franciscan' toes just peeking out. Emphasising over-sized material presence, the statue's overall weight is figured in its liturgical parts: the now damaged crozier is a giant crozier, the hands are gauntlets, the mitre is treated as a separate piece of goldsmith work. For the proAnjou and papal Parte Guelfa this 'gothic' crowning may have resonated with the golden papal mitre or tiara that Lorenzo Ghiberti claims to have had made for Martin $V$ with its halffigures worked in gold..$^{53}$ Although St. Louis is unique in Florence, a precedent, I would propose, is offered by the fully-gilded copper statue (over a wooden core), representing pope Boniface VIII in Bologna. Made in 1300, this still presided on the facade of the

\footnotetext{
52 For the senses of 'glory', see below and at note 97.

${ }^{53}$ Ghiberti, as at note 27 above, and Krautheimer, as at note 4 above, p. 13.
} 
communal palace during the residence of Baldassare Cossa there, who was Cardinal Legate to Bologna and a Florentine ally. Improbably youthful and similarly far beyond life size (at $275 \mathrm{~cm}$ ), this papal statue would have been well known to the Florentine Parte Guelfa as a 'partisan symbol' ordered in gratitude to Boniface, by Bologna's Guelf commune. ${ }^{54}$

The fascination of St. Louis' delicate, gilded face lies in the flawlessness and luminescence of its surface (fig. 7). The skin, because of its radiance, resists the haptic and the call to touch that Ghiberti declared could reveal the dolcezza of the body better than vision alone. ${ }^{55}$ The scarcely-defined eyes resist focus, as though blind to the present and turned to the world beyond. For all Donatello's naturalistic modelling, this combination of qualities relates to the tradition of the reliquary bust. We know that Donatello was engaged on an extraordinarily veristic and fully-gilded copper bust of San Rossore, with silvered eyes, in the mid 1420s, but

${ }^{54}$ A connection has not, to my knowledge, been previously recognised. For the 'statua ad similitudinem domini pape dorato' (now Museo Civico Bologna) as a Guelf statue see Cassidy, as at note 35 above, pp. 205-208; J. Gardner, 'Boniface VIII as a Patron of Sculpture', Roma anno 1300, Rome, L'Erma di Bretschneider, 1983, pp. 513-529 at p. 519; M. Cremonini Berretta, 'Il significato politico della statua offerta dai Bolognesi a Bonifacio VIII', in Studi di storia e di critica dedicati a Pio Carlo Falletti, Bologna 1915, pp. 422-431. See also M. S. Tumidei in M. Medica (ed.), Duecento. Forme e colori del Medioevo a Bologna, exh. cat., Bologna, Museo Civico Archeologico, Bologna, 2000, pp. 398-340; only the gloved hands are not gilded.

55 Ghiberti, as at note 27, above, p. 108. 
the head of St. Louis of Toulouse relates more directly to civic and episcopal reliquaries, like the bust of St. Zenobius of Florence (1331) or that of Bishop San Gennaro of Angevin Naples (1305, fig. 8 ). The latter, which also had a dynastic character, was designed to be furnished with a mitre for civic feast days. As containers for revered and potent body parts, such cult objects would have been more familiar to most Florentines than the gilded statuary of antiquity and, for the Parte Guelfa, invested as they were in Louis' sainthood and lineage, such a relation would have been far from unflattering.

As a representational presence containing actual bodily remains, this type of reliquary associates the gilded body with the liminal transformation of death. St. Louis of Toulouse, as statue and vision is hollow, but the work's reliquary-like preciousness and abstraction preserves the aura of a liminal and untouchable body. In this respect, the statue stands in stark contrast to the Christ and doubting St. Thomas group by Verrocchio that eventually, in 1483, filled the same niche at Orsanmichele (fig. 9). Here the flesh and blood depiction of St. Thomas's probing hand, raised in the act of affirming that Christ's body is not an apparition, sets itself against Louis' unfeeling gauntlet. In the complex topography, flow and relief of their robes, Verrocchio's figures pay homage to Donatello, but in the evocation of flesh and feeling, his replacement is also a critique.

Whereas the central gesture of the Christ and St. Thomas group draws the viewer in close to the body, the bishop saints' act of benediction and gilded surface spread its field of operation and hold the viewer at a distance. Blond and reflective, the figure would have been activated not only by occasional feast day devotions and candles, but by daily exposure to changing daylight. By the early Quattrocento, the broadened processional thoroughfare of via dei Calzaiuoli was wide enough along Orsanmichele's eastern flank to 
catch the sun at street level and, as has others have noted, morning light would have animated the statue, sometimes brilliantly. While Boffa was keen to see this effect as reinforcing an association with precious metal eucharistic vessels, the suggested relation of the sarcophagus-like base to a 'Christian altar', which underpins such an association, seems far from assured. ${ }^{56}$ This is, undoubtedly, a figure whose splendour -when its gilding was undimmed - was hard to ignore, catching the peripheral vision of the street walker or the incidental light of torches, it could suddenly manifest the presence of the saint, and the Party's interests. Any communal or common devotion it might have inspired at Orsanmichele was, though, short lived. By 1459, St. Louis had been removed by the Parte to the facade of S. Croce where, high up and deprived of its tabernacle, the sculpture lost its aesthetic coherence, its colour and its charisma. ${ }^{57}$ Alberti's comment on the changeability of devotees who, when a cult statue was moved, abandoned their devotion, seems well fitted to the fate of St. Louis of Toulouse. ${ }^{58}$

\section{A gold body in the Baptistery}

Hyper-visibility from a distance is a peculiar quality of the gilded body. Exploited for outdoor statuary reflecting the sun, it is effective, too, in dimly lit sanctuaries. This quality was

${ }^{56}$ Boffa, as at note 50 above, p. 289

${ }^{57}$ See Boffa, ibid., pp. 90-91. Giorgio Vasari (Le vite de' più eccellenti pittori, scultori ed architettori, (ed.) G. Milanesi, 2, p. 416), while recounting an early critique of it at S. Croce as 'goffa', recognised neither the figure's original position nor its gilding.

${ }^{58}$ De re aedificatoria, 6, Chap 17, Alberti, as at note 30 above, p. 663. 
undoubtedly at play in the choice to gild the effigy of Baldassare Cossa set high on his tomb in the subdued light of the Florentine Baptistery (c. 1424-28, fig. 10). ${ }^{59}$ The monument as a whole was made by Donatello, together with Michelozzo di Bartolommeo (his partner from 1425), and the successful fire gilding of the St. Louis could well have encouraged adoption of the same technique for the figure on the monument, especially given that the four executors of Cossa's will were members of the Parte Guelfa. ${ }^{60}$ The combination of gilding on a copper alloy was long established for princely effigies in northern Europe, but Cossa's was among the earliest bronze tomb effigies anywhere in Italy. ${ }^{61}$ Those of Leonardo Dati (Ghiberti) and Giovanni Pecci (Donatello), which were designed as floor slabs, are respectively coeval or later, and are not gilded. Yet neither Donatello's proficiency, nor the originality of the tomb design as a whole, are a sufficient 'cause' of the gilding. The highrelief effigy is functionally distinct from the statua of the saint, and different questions of interpretation attend its relation to the body. As a funerary marker, it presupposes proximity to the corporeal remains of the deceased. Its memorial and affective capacity, by bringing to mind the defunct in the reality of their death, could serve as a prompt to prayer

59 Lightbown, as at note 23 above, l, pp. 19-22 for dating.

${ }^{60}$ Zervas, as at note 23 above, p. 92.

${ }^{61}$ Goldenbaum, as at note 9 above, Sections II and esp. pp. 27-39, for a summary of gilded copper-alloy tombs from the thirteenth century onwards in Northern Europe (and see further at notes 77 and 78 below). Goldenbaum, ibid. Section III - V, for a close analysis of bronze gisants in Italy, esp. pp. 57-83; See also G. A. Johnson, 'Activating the Effigy: Donatello's Pecci Tomb in Florence Cathedral', Art Bulletin, 77, 1995, pp. 445-459. 
for an immortal soul assumed to be separate from the corpse and one whose fate - unlike that of the saint - was uncertain. ${ }^{62}$ This memorial 'doubling' of the mortal body in Donatello's emphatically portrait-like characterisation is crucially set in question by its supernatural splendour. Any discussion of the semiotics of Cossa's gilded figure has to contend with this productive tension between body and gilded surface.

Effigial tombs presupposed high status, especially in republican Florence, and the visibility of the body on the monument as at the funeral (a visibility prohibited to most Florentines), was valuable politically as well as spiritually. ${ }^{63}$ Just how complex the imbrication of the political and spiritual could be in a commemorative context was especially apparent in the case of Cossa. He died in December 1419 in the anomalous, and exceptional, state of a

62 P. Ariès, The Hour of Our Death, transl. H. Weaver, Harmondsworth, Penguin Books, 1981, esp. pp. 240-265 for changes in tomb effigies related to belief in the separation of the soul from the body at death.

${ }^{63}$ For the introduction of effigial tombs in Italy in the thirteenth century and their significance see, I. Herklotz, 'Sepulcra' e 'monumenta' del medioevo: Studi sull' arte sepolcrale in Italia, Rome, Rari Nantes, 1985 pp. 272-291 and 315 -337. For the status restriction (ecclesiastical or knightly) on effigial tombs in Florence see, A. Butterfield, 'Monument and Memory in Early Renaissance Florence', in G. Ciappelli and P.L. Rubin (eds), Art, Memory and Family in Renaissance Florence, Cambridge, Cambridge University Press, 2000 , pp. 135-160, esp. pp. 145-148, and for restriction on display of the body S. Strocchia, Death and Ritual in Renaissance Florence, Baltimore, Johns Hopkins University Press, 1992, pp. 171-2, 174-5 and 181. 
deposed antipope who had lost not just his right to rule, but his divine authority as Vicar of Christ and, with it, the 'golden key' to bind or loose souls in heaven. The often rehearsed story of how the one-time Pope John XXIII came to die as a cardinal in Florence needs brief telling. ${ }^{64}$ In the early 1400 s, Florence was increasingly tied by diplomatic and financial interests to the papacy through a period of continued schismatic crisis. At one point in the 1410s, three rival pontiffs were elected by rival Councils, one of them being Cossa. Swiftly ordained bishop and named as John XXIII by the Council of Pisa, he sided with the Angevin cause in his native Naples and tried to re-establish a presence in Rome before being deposed at the Council of Constance in favour of Oddone Colonna, elected pope Martin V in 1417. After fleeing Constance, leaving the papal tiara as security with Giovanni di Bicci de' Medici, Cossa was repeatedly imprisoned. It was Giovanni, his Florentine banker and close ally who channelled the funds for his ransom, while Florence offered him protection. ${ }^{65}$

${ }^{64}$ See G. Holmes, 'How the Medici became the Pope’s Bankers', in N. Rubinstein (ed.), Florentine Studies: Politics and Society in Renaissance Florence, London, Faber, 1968, pp. 357-376 at pp. 362-376. Comprehensive accounts are in Lightbown, as at note 23 above, I, Chap. 1; S. B. McHam, 'Donatello's Tomb of John XXIII', in M. I Tetel, R. G. Witt and R. Goffen (eds), Life and Death in Fifteenth-Century Florence, Durham, Duke University Press, 1989, pp. 146-175; and Goldenbaum, as at note 9 above, pp. 140-148.

${ }^{65}$ Brucker, as at note 42 above, for the longer term, often conflicted relationship between John XXIII and Florentine interests, esp. pp. 364-366, 372-376; Lightbown, ibid., pp. 6-7; McHam ibid., pp. 153-4 and, for the significance of Giovanni de' Medici's role in the tomb, pp. 156-7. 
While maintaining allegiance to John, the city had benefitted too from Martin V's residence. ${ }^{66}$ It was in Florence's interests to host a reconciliation, which took place at S. Mara Novella in June 1419; Cossa was raised to a renewed cardinalate but died just a few months later. His will was to be buried in the Baptistery, the patronal church of his name saint as pope, but the Calimala Guild were cautious in conceding the exceptional privilege of a sepulchre there, fearing for its instrusiveness. ${ }^{67}$ Nothing short of a claim to papal status (he is declared, ambiguously, 'John XXIII quondam papa' in antique majuscules on the tomb) and the favours with which Cossa had leveraged the city's good will would have made it possible. Giovanni de' Medici was one of Cossa's executors and it was, in all likelihood, his son Cosimo who oversaw the tomb, ensuring that Medici political interests, knowledge and capital were also at play in its magnificence. ${ }^{68}$ Giovanni di Bicci could boast experience of bronze sculpture from the moment of his involvement in the committee judging the competition reliefs for the Baptistery's New Testament doors in 1401 and, more recently, from his sourcing of a suitable alloy for Ghiberti's St. Matthew in Venice on behalf of the

${ }^{66}$ Cossa had helped Florence to take the port of Pisa while Cardinal Legate of Bologna,.

${ }^{67}$ V. Herzner, 'Regesti Donatelliani', Rivista dell'Istituto Nazionale d'Archeologia e Storia dell'Arte, 2, 1979, pp. 169-228 at p. 69; D. Kent, Cosimo de' Medici and the Florentine Renaissance: The Patron's Oeuvre, New Haven and London, Yale University Press, 2000, pp. 164-6.

${ }^{68}$ Kent, ibid, p. 166. 
Banker's Guild. ${ }^{69}$ But the immediate agency of the Medici could not have been decisive without Florentine loyalty to Cossa, the so-called 'Cardinal of Florence'. Laura Goldenbaum's telling assertion in respect to Cosimo de' Medici's role that the effigy is 'not by accident [...] the colour and material of the fiorino d'oro', speaks more broadly to the value of a 'tried' and trusted coin employed for the gilding and, to the material and political investments of the mercantile oligarchy in the 1420s, including that bastion of the ottimati, the Calimala. ${ }^{70}$

On the other side of this precious coin, Baldassare Cossa had granted the Florentine clergy the right to celebrate the salvific Festa del Perdono and, among many benefactions to churches in his will, gave a relic of the Baptist's finger to the patronal church (that had cost him 800 florins) together with the funds to commission its gilded reliquary. ${ }^{71}$ Whereas, outside Florence, Cossa had a reputation as a venal and, to some, vicious figure, the sermon at his funeral urged that he was already ripe for resurrection as a result of his charity, as

${ }^{69}$ A. Doren, Das Aktenbuch für Ghibertis Matthäus-Statue an Or San Michele zu Florenz, Berlin, Bruno Cassirer, 1906, pp. 31-2.

${ }^{70}$ Goldenbaum, as at note 9 above, pp. 137-138, noting that Cossa was close to 'ruined' by 1419.

${ }^{71}$ Lightbown, as at note 23 above, pp. 9-10. 
well as for bringing peace and union to a divided church. ${ }^{72}$ His tomb and its reliefs of Faith, Hope and Charity make similarly lofty assertions about Cossa's saving virtues in life, and, I would argue, the gilded body participates materially and dramatically in the claims for his post-mortem future (fig. 10).

Framed by the mordant-gilded tassles of a rich, canopy, Cossa's life-size recumbent figure is revealed under the protection of the Virgin and Child. He wears a mitre and the softly settling folds of a dalmatic, chasuble and bishop's gloves show the body at rest. The face lined, slightly sagging, but with vividly curling eyebrows - is exposed towards the viewer (fig. 11). ${ }^{73}$ The bronze body, cushion and pall cloth are a tour de force of technical as well as expressive virtuosity, cold worked to the highest finish. ${ }^{74}$ Though it is not certain from surface examination that they were cast in one as a single relief, the gilding suggests this by the significant fringe of gold overlapping the cloth around the figure, and spilling out beyond the stole. ${ }^{75}$ The effect of the transfiguration of the whole figure by gold is currently

\footnotetext{
72 McHam, at note 64 above, p. 235, note 20 for the sermon, whose scriptural sentence was taken from Christ's presentation in the temple, Luke 2, v. 34 (Milan, Biblioteca Ambrosiana MS P 259 supp. Cc. 53-6).
}

${ }^{73}$ Lightbown, as at note 23 above, pp. 45-6 for his (cardinal's) garments.

74 Goldenbaum, as at note 9 above, pp. 172-8 for detailed observations on finish.

75 Lightbown, as at note 23 above, for these dimensions; H. W. Janson, The Sculpture of Donatello, I, Princeton, Princeton University Press, 1957, pp. 63-4 and 57-8 proposes that 
exaggerated by spot-lighting, but the differentiation between body and setting was always intended to be stark. The entire figure is evenly gilded and burnished in a way that harvests the light of day, or of votive candles, so that it stands out against the darkly-patinated foil of cloth. As Dale Kent has indicated, the sun illuminates the effigy directly in the early morning so that it shines out in the space of the Baptistery. ${ }^{76}$ What, then, would the intrinsic brightness of this figure, and the intensified splendour borrowed from the eastern sun, have signified?

The effigy's materiality certainly signals the 'honour and fame' of the quondam papa, whether in its manifest expense or in the way that it could, for well-travelled Florentines or members of the curia, recall the gilded copper-alloy effigies of sovereign or princely subjects in northern Europe. Many of these, including royal couples, still cluster around the shrine of Edward the Confessor at Westminster Abbey (from the 1290 s to 1390 s). ${ }^{77}$ One or two have

Giovanni di Jacopo degli Strozzi, who cast the San Rossore bust for Donatello in the same years, may have undertaken this casting too. For Donatello's collaborations and casting see Motture, as at note 7, above, p.p. 119-120. There has been no technical analysis of the casting structure, but the photographic record, and the extent of the gold beyond the figure, support the presumption that the trunk of the body and pall cloth were gilded as one piece.

76 Kent, as at note 67 above, p. 166.

77 P. Binski, Westminster Abbey and the Plantagenets: Kingship and the Representation of Power, 1200-1400, New Haven and London, Yale University Press, 1995, pp. 107-120 and 
survived in France, but many more are recorded there from the later middle ages. ${ }^{78}$ Reflected glory belongs, as we have seen, to the city, its governors and the ascendant Medici. But it is the specific location of the gilded effigy in the Baptistery that, above all, gives the figure its enduring spiritual eloquence and justification, its theological as well as optical splendor. ${ }^{79}$ Centred in a temple of considerable antiquity, the great octagonal structure of the Baptistery font was used at the feasts of Easter, Pentecost and Epiphany for the infant baptism of Florentine citizens. ${ }^{80}$ The Baptistery was also a place of civic votive offering and consecration, with a magnificent silver altar which, with its liturgical silver accoutrements, was installed annually (latterly above the font) for the June feast of 'San

195-202 for these gilded metal royal tombs and their decorum; Lightbown, as at note 23 above.

${ }^{78}$ S. Badham and S. Oosterwijk, "Monumentum aere perennius'? Precious-metal effigial tomb monuments in Europe 1080-1430', Church Monuments, 30, 2015, pp. 7-105

${ }^{79}$ For a summary of terms used in optics and the theology of light, including splendor and fulgor as they would have been understood in learned circles in this period see P. Hills, The Light of Early Italian Painting, New Haven and London, Yale University Press, 1987, pp. 1118.

80 Daily baptisms took place at a separate, smaller font. 
Giovanni' ${ }^{81}$ Silver was a recognised material for votive objects in Florence and, deemed a 'white' metal that might symbolise purity. The Baptistery treasures would be joined, in 1421, by the gilded silver reliquary of St. John the Baptist's finger donated by Cossa (fig. ). Goldenbaum has argued for a close material, and thus associative, relationship between the reliquary as saintly container and the gilded bronze effigy, which could confer an aura of sacrality on the cardinal's remains. ${ }^{82}$ In fact the work was rarely experienced together with the tomb, but it is certainly the case that the relic, bringing honour and charisma to Florence, formed a powerful link in the chain of obligation ensuring intercession for Cossa's soul, awaiting reintegration with his body at the general resurrection. ${ }^{83}$ With the granting of the Festa del Perdono (Day of Pardon on 13 January) in 1413, John XXIII had effectively extended the possibility of annual and complete cleansing from sin to the city's religious orders. In the economy of salvation, this remission cancelled years of atonement in Purgatory and, for any penitent dying with this pardon, ensured the soul's direct passage to Heaven. What the Baptistery could offer in exchange for such spiritual benefits was posthumous honour, masses said for Cossa's soul and burial by the font, a site of symbolic death and rising to new life.

81 A. Wright, The Pollaiuolo Brothers: The Arts of Florence and Rome, New Haven and London, Yale University Press, 2005, pp. 286-288.

${ }^{82}$ Goldenbaum as at note 7 above, pp. 153-164, esp. 162-163.

${ }^{83}$ P. Binski, Medieval Death: Ritual and Representation, London, British Museum, 1996, pp. 21-28 for practices of intercession for the soul in purgatory. 
The post mortem rites of passage for Cossa shed some light onto the gilded effigy.

Description of the obsequies of December- January 1420, financed by the government to the tune of 300 florins and lasting nine days (the Novena of the Roman Rite), indicates that this was also taken as an opportunity to enhance communal honour. ${ }^{84}$ The catafalque in the cathedral was a true chapelle ardent, surrounded by princely conflagrations of the best candles, by masses to speed Cossa's soul, and offerings of precisely-valued Florentine figured silks give $\mathrm{n}$ by the Commune and Parte Guelfa. ${ }^{85}$ But it is the solemn Vigil that had already taken place on the evening of the prelate's death that seems the most telling of these rites in respect to the effigy, since his mortal remains were present and centred in the Baptistery. Wearing a white mitre and open to view, Cossa's body was processed by the canons of the cathedral from the house in which he had died into the church, where his bier, covered with a white pall cloth - not the papal cloth of gold -was placed directly over

${ }^{84}$ Strocchia, as at note 63 above, pp. 137- 143. For the ceremonial of curial funerary rites in the Renaissance (and aspects of the liturgy, particularly the Ordo romanus XV) see esp. I. Herklotz, 'Paris de Grassis Tractatus de funeribus et exequiis und die Bestattungsfeiern von Päpsten und Kardinälen in Spätmittelalter und Renaissance', in J. Garms and A. M. Romani (eds), Skulptur und Grabmal des Spätmittelalters in Rom und Italien - Europäische Perspektiven, 1990, Vienna, Verlag der Österreichisches Akademie der Wissenchaften, 1990, pp. 217-248.

85 Bartolommeo del Corazza, Diario fiorentino (1405-1439), (ed.) R. Gentile, Rome, De Rubeis, 1991, pp. 58-59. Strocchia, ibid. pp. 139-142. 
the central font. ${ }^{86} \mathrm{His}$ body was thus elevated during the Office of the Dead, comprising Vespers, the Mass and, presumably, the prayer of Absolution with the asperging and censing of the defunct. ${ }^{87}$ The liturgy asks for the intercessory prayers of the Virgin and saints, pardon for sin, and makes repeated supplication for mercy and deliverance at the end of time: '[...] When the heavens and the earth shall be moved. That day of wrath [...] when thou comest to judge the world by fire'. This Responsory (from the Libera me, Domine), is followed by the Versicle: 'Eternal rest grant unto them O Lord' 'And let thy light perpetual shine upon them' 'May they rest in peace' ${ }^{88}$

${ }^{86}$ Corazza (ibid., p. 56) describes it then being placed beneath a canopy (pergamo), where it was surrounded by candles: 'La sera di ditto sabbato si trasse il suo corpo di casa d'Antonio di Santi, dove era morto; e fu portato in San Giovanni in su la bara scoperto, parato d'un paramento bianco di drapo. Con la mitra Bianca in capo, e col capello da cardinal alli suoi piedi in su unco guanciale. Portarono i calonici [canons] di Santa Liperata con tre croci: I'una di San Giovanni, I’altra di Santa Liperata, l'altra di Santa Maria Maggior. Posonno la bara sopra le fonti di San Giovanni e disso l’officio; poi misseno sotto ‘l pergamo, e ivi stette con molti doppieri accesi, insino al dì che si fé l'ossequio suo...' The body was placed back on the font for the third requiem of the Novena (Strocchia, ibid. pp. 142-3 and Goldenbaum, as at note 9 above, pp. 151-2). Strocchia, as at note 84 above, p. 81 for the introduction of this ritual at the Baptistery in 1394 for the funeral of the Sir John Hawkwood.

${ }^{87}$ Binski, as at note 83 above, pp. 50-55 for the Office of the Dead in this period and for masses for the dead, pp. 92-111 
With this powerful staging above the font and the effulgence in the darkness - especially the concentrated radiance of candles around the body on the bier - the Vigil anticipated the permanent gilded effigy, likewise resting on a (lion-headed) bier. Could the radiance of the effigy, then, be construed as a reflection onto the cardinal's body of the 'perpetual light' of God of the liturgy? The mighty figure of Christ as Judge in the golden vault directly above, and the elevated position of the sculpture, so different from that of earlier gilded tombs, might encourage such an interpretation. Sarah Blake McHam has expounded the vital theological relationship among the sacrament of baptism, resurrection in Christ and Last Judgement that made Cossa's entombment in a baptistery a potent burial ad Christum. ${ }^{89}$ The proximity of the tomb to the font, from which the new Christian emerges 'dead to sin', and to the eschatological representation in the vault of the enthroned Christ in Glory, offers, I would suggest, a more active and radical possibility than the reflection of eternal light:

${ }^{88}$ For the history of the Office in the ancient Roman Rite see F. Cabrol, 'Office of the Dead', in C. Herbermann (ed.), Catholic Encyclopedia, 11, New York, Robert Appleton, 1913, pp. 220-221, and for historical and local variation, K. Ottosen, The Responsories and Versicles of the Latin Office of the Dead, Copenhagen, Knud Ottosen, 2007, Chaps 1 and 2.

$89 \mathrm{McHam}$, as at note 64 above, pp. 162-3. See also D. Hoogland Verkerk, 'The font is a kind of grave: Remembrance in the Via Latina Catacombs', in E. Valdez Del Alamo and C. Stamatis Pendergast (eds), Memory and the Medieval Tomb, London, Routledge, 2000, pp. 157-182. The baptistery of San Marco in Venice was the chosen burial place of another John, Doge Giovanni Soranzo (d. 1328), and the Carystian marble revetment of his tomb has waved veining that directly evokes the waters of Baptism. 
namely that of a transformation of Cossa's body by supernatural power, suddenly and as though from within. The resurrection vision of the Prophet Daniel declared that amongst those awaking from the dust of the earth to eternal life, the 'wise leaders shall shine like the bright vault of heaven' ${ }^{90}$ Most pertinent of all to the temporality of the gilded effigy was the more familiar Pauline conception of what happens to the wasted flesh of the dead at the end of time (1 Corinthians 15): 'Behold, I shew you a mystery; We shall not all sleep, but we shall all be changed, In a moment, in the twinkling of an eye, at the last trump: for the trumpet shall sound, and the dead shall be raised incorruptible, and we shall be changed. For this corruptible [body] must put on incorruption and this mortal must put on immortality [...] then shall be brought to pass the saying that is written, Death is swallowed up in victory'. ${ }^{91}$ Such 'putting on' of incorruption marks a substantial change. While, in the mosaic, the naked dead clamber out of their tombs towards divergent fates, Cossa's complete gilding fulfils the prophetic promise of victory over death.

\footnotetext{
${ }^{90}$ Daniel 12, vv. 2-3.
}

911 Corinthians, 15, vv. 51-54. For scholastic theology, 'man' is a composite of form and matter but, contra-Aristotle, he has a soul infused by God that both antedates and survives the body. The duality is not absolute, though, since the body also participates in the unique being of the soul, hence the ultimate need for bodily resurrection. See A. Boureau, 'The Sacrality of One's Own Body in the Middle Ages', in F. Jaouën and B. Semple (eds), Corps Mystique, Corps Sacré: Textual Transfigurations of the Body from the Middle Ages to the Seventeenth Century, New Haven and London, Yale University Press, 1994, pp. 5-17. 
The longstanding metallurgical conception of the 'living' quality of bronze alloy as a material that transforms (and substitutes) in the casting process has been widely explored, preeminently for the Renaissance by Michael Cole, who also noted how Cellini termed the casting core the 'anima' of the statue..$^{92}$ In the Cossa effigy, animation is presented not as intrinsic to the bronze itself, but made visible, on the surface. As a figure for corrupt flesh turned to incorruption with a trumpet blast, the dead body, formed in a brazen alloy and transfigured by pure and luminous gold, whose virtù derived from the sun, could scarcely be more eloquent. Even the overspill of gilding beyond Cossa's chasuble and stole on to the untransformed pall cloth - which could be construed as lavishness with the amalgam enhances the effect of a dense brilliance radiating from the body, as opposed to light falling onto it. Purgatory's dominant figure, deriving from 1 Corinthians, 3 , vv. 13-15, is one of testing by fire, of burning away of sin before the soul is fit for heaven, and it accorded with the powerful and familiar Old Testament image of God refining his people, like gold or silver,

92 M. W. Cole, Cellini and the Principles of Sculpture, Cambridge, Cambridge University Press, 2002, Chap 3. For the Middle Ages see, recently, I. Weinryb, The Bronze Object in the Middle Ages, New York, Cambridge University Press, 2016, esp. pp. 51-54. See further for Renaissance beliefs and practices concerning the formation and properties of metals, alchemy, casting and alloys, F. Scholten, 'Bronze, the Mythology of a Metal', in M. Droth, F. Scholten and M. W. Cole (eds), Bronze: The Power of Life and Death, exh. cat., The Henry Moore Institute, Leeds, 2006, pp. 20-35 and Motture, as at note 7 above, pp. 13-25, 125 and 229. 
in the fire. ${ }^{93}$ This was a prophetic, emotive, but also vividly concrete image. Pliny the Elder speaks of gold's most valued quality as its capacity to withstand the test of fire without loss; fire rather 'proves' or refines its goodness. ${ }^{94}$ More specifically, the gold on Cossa's body could invoke, as material and symbol, the now tried and purged anima, bonded again with the body and readied to be 'raised incorruptible' at the General Resurrection. That Donatello himself could think in terms of such a material narrative of transformation is suggested in many works, not least in the enveloping gilded hair of his penitent Magdalen, or the selective gold ornament across the sandstone relief of the Annunciation tabernacle in

93 J. Le Goff, The Birth of Purgatory, Chap 4, 'The Fire of Purgatory'. Biblical sources include Malachi 3, vv. 2-3 (as prophecy of God's coming in judgement); Psalm 66, v. 10; Jeremiah 9, v. 7; Daniel 11, v. 35.

${ }^{94}$ Pliny, as at note 25 above, Book 33, Chap. 19: 'gold is the only thing that loses no substance by the action of fire, but even in conflagrations and on funeral pyres receives no damage. Indeed, as a matter of fact it improves in quality the more often it is fired, and fire serves as a test of its goodness [bonitatem], making it assume a similar red hue and itself become the colour of fire; this process is called assaying', (Pliny the Elder, Natural History, (transl.) H. Rackham, London, Heinemann and Cambridge MA, Harvard University Press, 1952, pp. 47-49). 
S. Croce, representing the humble Virgin transfigured by the Holy Spirit, the 'Ark that the spirit has gilded'. ${ }^{95}$

The sculpted effigy in the Baptistery and its transfigured surface hold together the past of the displayed body at the Vigil, the present (and presence) of the interred corpse and its future transformation, which accompanies victory over death. The visual and material means by which the effigy produces this temporal collapse is closely tailored to the Florentine Baptistery and the deceased's special relationship to it. This is not the 'gilded victor' all'antica, of the kind secured with Bartolommeo Colleoni's later equestrian effigy for his tomb in Bergamo. ${ }^{96}$ While undoubtedly honorific, its meaning in situ is less strongly determined by the need to return to Cossa some lost princely authority, fame or earthly glory, than by its capacity to invoke spiritual 'glory' that has withstood trial. ${ }^{97}$ Biblical gloria (doxa in the New Testament) covers a wide semantic field, referring at some moments to the brilliant, radiant splendour associated with God's presence, at others to majesty and

${ }_{95}$ Quoting from the Akathistos Hymn. See A. Wright, Frame Work: Honour and Ornament in Italian Renaissance Art, New Haven and London, Yale University Press, 2019, pp. 209-211 and $213-214$.

${ }^{96}$ See J. Kohl, Fama und Virtus. Bartolomeo Colleonis Grabkapelle, Berlin, Akademie-Verlag, 2004 , pp. 50-52 for the tortured progress of this sculpture, eventually remade in wood by 1500 but gilded only in 1516.

97 Goldenbaum, as at note 9 above, p. 139 and pp. 146-8, emphasises the former meaning, citing Poggio Bracciolini's funeral oration for Cardinal Francesco Zabarella. 
honour, or, to might and power. ${ }^{98}$ Christ's apocalyptic 'coming again with glory to judge the living and the dead', is imagined to involve all three senses of gloria.${ }^{99}$ Christ's coming is anticipated, moreover, in the orientation of Cossa's body on the tomb - facing not towards the main altar of the Baptistery, to the west, but to the east, from which the Last Judgement was awaited.

There is, conveniently, no way to distinguish between the conferring of gold on the body as generalized splendor, reward for achievement, fulfilment of obligation by a donor (from the city, from the Medici) or as gift of grace. ${ }^{100}$ Moreover the meaning of the fully-gilded effigy, especially for such an ambivalent subject as Cossa, was not only unstable over time, but would have varied according to the mores and knowledge of contemporaries. For someone like the learned Pala Strozzi, for example, who had wanted to contain the scale of the tomb,

${ }^{98}$ E. Fry, 'Translating 'glory' in the New Testament', The Bible Translator, New York, The American Bible Society, 1976, pp. 422-426.

99 'Et iterum venturus est cum gloria, iudicare vivos et mortuos [cuius regni non erit finis]' From the Nicene Creed, used in the Mass of the Ordo Romanus.

100 Kent, as at note 67, above, p. 166, for the problem here, and more generally, of pinpointing intentional 'self-promotion' by Cosimo in a civic context. 
gilding might well have looked hubristic, and antique. ${ }^{101}$ Yet the liturgical function of the Florentine Baptistery, its dominant imagery and the intensified illumination the gilded effigy gained from the east, could all serve the proleptic claim of a future glory. A recent decision to dramatise the interior of the church with lighting designed by Vittorio Storaro, Oscarwinning cinematographer of 'Apocalypse Now', contributes a note of irony to the disruption of the daily cycle of light experienced by the effigy in San Giovanni. ${ }^{102}$

\section{Golden Boy}

A paradoxical quality of the fully-gilded body is that it can be at once highly visible and marginal. The effigy of Baldassare Cossa is a liminal figure par excellence in being positioned between states: recumbent in death, the body is permanently suspended in a moment of transformation. Such a quality attends, in a different way, the last completely gilded figure to which this discussion turns - the gold-bodied spiritello or winged boy - of which the largest early fifteenth-century bronze to survive, at $61.6 \mathrm{~cm}$, is the 'blowing sprite' now in the Metropolitan Museum of Art, New York (fig. 12). ${ }^{103}$ Though Donatello's many putto-

${ }^{101}$ Kent, ibid. p. 166; Sénéchal (as at note 9 above, p. 105) refers to this potential for Cossa's complete gilding to be condemned as a sign of hubris.

${ }^{102}$ https://firenze.repubblica.it/cronaca/2018/05/03/news/firenze nuova luce per il batti stero_col_progetto_di storaro-195437302/Accessed 27.11.2019.

103 See J. D. Draper, in Italian Renaissance Sculpture in the Time of Donatello, exh. cat. Kimbell Art Museum, Detroit, 1985, pp. 126-7; I. Wardopper, European Sculpture, 14001900 in the Metropolitan Museum of Art, New Haven and London, Yale University Press, 
spirits are some of his greatest inventions, and encompass the pair of once fully-gilded bronze angels for an organ loft of the Duomo, the Metropolitan figure is addressed here for its secular and domestic character, its large scale $(61.6 \mathrm{~cm}$ high) and its setting at an early date, a setting that aligns it with a longer history of all'antica bronzes as privately-owned works. ${ }^{104}$ As a sizable gilded statue for a palace it remains, nonetheless, isolated in fifteenthcentury Florence, for what were likely to be political as much as aesthetic reasons.

The shifting surface quality of gilded bronze is one that complements the figure's hybridity. The naked boy has the wings of a bird, sprouting thickly across the back and shoulders, as well as feathered ankles and a furry tail. The mixing of male human and animal in this body is both learned and humorous: part playful child, young Mercury (with his winged feet), blowing wind-god (Draper proposes the gentle Zephyr/ Favonius), he also possesses a teasing tail - as of a faun - to be discovered from the rear. Even the stance, poised as though between earth and sky, is related both to ancient works and to Donatello's small,

2011, pp. 11-12 (NB 'Palazzo Vecchio' is an error for its putative location) and Draper in Paolozzi Strozzi and Bormand (eds), as at note 5 above, p. 354, cat. n. IV. 8, with recent bibliography. The impressively intact original fire-gilding was revealed from under a black patina when the work was examined at the V\&A in the 1970s (see A. P. Darr and G. Bonsanti (eds), Donatello e i suoi: Scultura fiorentina del primo Rinascimento, exh. cat. Florence and Detroit Institute of Art, 1986, p. 140).

${ }^{104}$ For the once candle-bearing spiritelli for Luca della Robbia's organ loft, see Paolozzi Strozzi and Bormand (eds), as at note 5 above, pp. 352-3. 
gilded spiritelli, dancing and playing instruments (1429), joyful bodies who have alighted on the ciborium of the Siena Baptistery font. ${ }^{105}$

Though the movement is more tentative and modelling less subtle than Donatello's, the figure's invention is characteristic for him, and a connection with the early Medici, who were the sculptor's wealthiest and most ambitious patrons, can been established. The sculpture, which had piping running through the supporting leg and could spout water through its mouth, has been identified, convincingly to the present author, with the gilded 'idolo' attached to a bronze ball, which was once installed above the basin of a wallmounted fountain belonging to the Casa Vecchia of Giovanni di Bicci (d. 1429) in Florence' via Larga. ${ }^{106}$ The record of a painter supplying gold leaf for the 'spiritello sopra il pozzo' in March 1432, has suggested the figure was already situated in the small urban garden of the first Medici palace shortly before Cosimo de' Medici's temporary exile by the Albizzi faction in 1433 , and at a time when Cosimo's political influence was already exciting opposition. ${ }^{107}$

105 Draper, in both citations in note 102 above. For antique bronze children in 'running' poses see A. Butterfield, The Sculptures of Andrea del Verrocchio, New Haven and London, Yale University Press, 1997, pp, 130-131. For the angels on the Siena font; F. Caglioti, 'Donatello e il Fonte Battesimale di Siena. Per una rivalutazione dello 'Spiritello danzante' nel Museo Nazionale di Firenze', Prospettiva, 110/111, 2003, pp. 18-29.

106 The idolo's materials are recorded in a 1503 list and its placement in an inventory of 1516, see D. Carl, 'La Casa Vecchia dei Medici e il suo giardino', in G. Cherubini and G. Fanelli (eds), Il Palazzo Medici Riccardi di Firenze, Florence, Giunti, 1990, pp. 38-43 at pp. 41-42. 
The commission and personal ownership of such an original bronze would, still more than the fountain itself, imply exceptional distinction: by its materials, its claims to antique erudition, to prosperity and its appeal to the poetics of pleasure, rather than edification. The early sixteenth-century descriptions establish that, whatever its specific identification might have been, the figure was taken by that date to be a pagan god and that it was quite literally, a sensational object.

The golden boy was highly performative. The stream of water issuing from the mouth, like breath, was designed to rotate a spinner held in the raised hand. Thus the movement invoked by the pose and golden surface was enacted by the continuous - and bountiful stream of water, an ingenious and beneficent flow that would have splashed back over the shining skin, in a play of sound and light. Crucially, the inflated cheeks and spinner manifest how water, bountifully springing from the source, behaves like wind: what Cole, in his analysis of Giambologna's bronze Mercury, described in aptly Aristotelian terms as a dynamic 'exhalation of vapour'. ${ }^{108}$ The Metropolitan bronze is a younger idol, both animal and avian, with other-worldly, 'splendid' skin, which visually reduces the weight of the body

107 This seems unlikely, however, to have been the gold used in the fire-gilding, which would have to have been applied after casting but before installation.

${ }^{108}$ M. W. Cole, 'The Medici 'Mercury' and the Breath of Bronze', in P. Motture (ed.), Large Bronzes in the Renaissance, Studies in the History of Art, 64 , New Haven and London, Yale University Press, 2003, pp. 129-153. Starting with Giambologna's Mercury, Cole elaborates on the god's presiding over water in the heavens (Ovid, Fasti, 5, 673-692), and on the relation of bronze founding to the control of exhalation from fiery matter. 
(the sculpture now weighs some $136 \mathrm{~kg}$ ). As such, it seems close, too, to the spiritelli analysed by Charles Dempsey, which, as mischievous spirits or pneumas, elusively animate the body, as much as the psyche. ${ }^{109}$ Here again, the gilded surface serves to enhance a sense of implied movement and change: winged and fugitive, the idol looks poised to evaporate or 'quicken', like the very mercury by which his bronze body was turned to gold. If this sculpture was once thought of as a boy Mercury, and not only a mercurial figure, then the association between the Medici and flourishing commerce would have been direct. Francesco Caglioti, dating the sculpture to a later moment c. 1460, argues tentatively that the bronze might have graced a marble fountain in the garden of the new Medici palace (a work he identified in the Pitti palace). The inscription on the Pitti fountain refers, somewhat cryptically, to the 'Deus aureus' who will, with water, change men into birds and diamonds. ${ }^{110}$ Whether or not this is the same 'golden god' as the New York figure, it was the brilliance of its very materials, dramatised by water, which would have allowed the fountain figure to embody the transforming powers of Medici prosperity and patronage.

${ }^{109}$ See C. Dempsey, Inventing the Renaissance Putto, Chapel Hill NC, University of North Carolina Press, 2001, pp. 40-61, drawing on fifteenth-century Aristotelian and Galenic thought.

110 'Ne sis preda tuis, Atheon, Deus aureus unda / In volucres vertit vel adamant viros' ('So that you, like a new Actaeon, are not prey to your own, the gilded god changes men into birds and diamonds with water') ie. into adherents of the Medici, referring to their 'diamond' and 'bird' emblems. See F. Caglioti, Donatello e i Medici: Storia del David e della Giuditta, Florence, Leo S. Olschki, 2001, p. 365 and pp. 371-377. 
The notably 'civic' material of bronze would be used elsewhere by the Medici in the 1430s, but it is only works for an ostensibly domestic setting that came with such splendour - like the pagan-looking David of Donatello, with his long golden hair and gilded ornaments.

As an object, the New York sculpture bears signs of wear and repair. ${ }^{111}$ As an idea, it belongs to a class of winged spirits and mythological hybrids that, in the course of the fifteenth century constantly multiplied in the role of liminal or crowning figures, active ornaments and inventions. Some were golden messengers, often bearing light, wind or water. Others were martial and emblematic, like Bertoldo di Giovanni's fully-gilded, pendant shieldbearers. ${ }^{112}$ The particular performative character of the gilded fountain figure, and its political significance in context, seems still clearer when seen in relation to temporary stagings where golden boys materialised in the flesh. At the notoriously lavish, all'antica entertainment staged by Cardinal Pietro Riario for the Neapolitan princess Eleonora of Aragon and Ercole d'Este, at his Rome palace in 1473, the animation of the ancient idol pagan, elevated, brazen - was completed by employing an actual child, his naked body

${ }^{111}$ See Draper, as at note 103 above, p. 127.

112 See recently A. Noelle in A. Ng, A. J. Noelle and X.F. Salomon (eds. ), Bertoldo di Giovanni: The Renaissance of Sculpture in Medici Florence, exh. cat., The Frick Collection, New York, 2019 , cat. nos. 4 and 5, and related essay at pp. 155-187. The antiquarian fantasy of the Hypnerotomachia Poliphili (Venice 1499) is full of such figural ornaments. 
gilded, to enchant the guests. Standing above a column, he showered water, now one way, now another, from a fountain. ${ }^{113}$

The liminal status of the child, which sanctions this questionable transformation of youthful skin, also places the body in danger, though not for the mythical reason perpetuated by lan Fleming's Goldfinger, in which the naked 'Bond girl' is suffocated by gilding. Instead, Vasari's story from the celebration for pope Leo X de' Medici in Florence in 1515 exposes, almost accidentally, the stakes for such a marginal body. ${ }^{114}$ The festive triumphal chariot representing the 'Age of Gold' bore a great globe of the earth upon which, 'there lay prostrate on his face, as if dead, a man clad in armour all eaten with rust, who had the back open and cleft, and from the fissure there issued a child all naked and gilded, who represented the new birth of the age of gold and the end of the age of iron, from which he

113 B. Corio, L'Historia di Milano, Padua, Paolo Frambotto, 1646, pp. 821-2. 'Et allato era posto sopra una colonna un fanciullo vero nudo indorato in forma d'Angelo, che gettava acqua da un Fontana, hor quà, hor là, variando'. My thanks to Kate Lowe for pointing me to Burckhardt (The Civilisation of the Italian Renaissance in Italy, London, Phaidon, 1951, p. 252) who referred to the figure in Riario's entertainment. For the temporary setting as representing Elysium, M. Licht, 'Elysium: A Prelude to Renaissance Theater', Renaissance Quarterly, 49, no. 1, 1996, pp. 1-29 and esp. pp. 5 and 20. Licht's translation makes the boy a putto mictans, but this is not explicit in the description.

114 Vasari, as at note 57 above, vol. 6, pp. 254-255. 
was coming forth into that new birth by reason of the election of that Pontiff'. Such a metallic re-birth from death to new life, corruption to incorruption, recalls that proposed here for the Cossa tomb. But behind the scenes all is far from golden - 'I should mention', Vasari continues, 'that the gilded boy, who was the son of a baker, died shortly afterwards through the sufferings that he endured in order to gain ten scudi.' Though spun by Vasari as a consequence of boyish greed, such a casualty of Medici symbolism is symptomatic of the vast economic and social disparities that characterised Renaissance Florence. And for the story to enter Florentine urban myth indicates, too, its potential as a sign of ill omen for the city and the questionable benefits of Medicean rule. For the same occasion, Baccio Bandinelli produced a gilded-stucco giant of Hercules for the Loggia of the Signoria, a Florentine symbol certainly, but one transfigured in the imperial terms of the gilded bronze Hercules Boarius, a colossus unearthed under pope Sixtus IV. ${ }^{115}$ For those Florentines who had welcomed the family's expulsion in 1494, it would have been the 'returned' Medici Age that represented civic corruption, not the Republic that had preceded it (1494-1512).

By 1495, when the Medici palace bronzes of Judith and David were transferred to the town hall as signs of reclaimed republicanism, total gilding had long dropped out of the realm of Florentine public sculpture. In the 1450 s Donatello had won the commission for a statue of the new overlord of Modena, Borso d'Este, proposing it be made in fire-gilded bronze to ensure its longevity; but, in the Florentine Baptistery, Michelozzo's St. John the Baptist, at

\footnotetext{
${ }^{115}$ Vasari, as at note 57 above, 6, pp. 141-2; V. L. Bush, 'Bandinelli's 'Hercules and Cacus and Florentine Traditions', Memoirs of the American Academy in Rome, 35, Studies in Italian Art History 1, 1980, pp. 163-206, at pp. 171-173.
} 
the centre of the silver altar was gilded selectively, leaving his skin as polished silver. ${ }^{116}$ More significantly, complete gilding was eschewed in prominent commissions for bronze statuary in the second half of the Quattrocento, whether at Orsanmichele (Verrocchio, fig. 9) or for the popes in Rome. ${ }^{117}$ The supposedly 'humble' floor tomb of Sixtus IV by Antonio del Pollaiuolo for St. Peters, while highly polished and in high relief, has no gilding. That of his successor, Innocent VIII, has gold applied to all its liturgical and other ornaments. But the pope's flesh (and that of the surrounding Virtues) is left bare, both on his recumbent effigy and on his enthroned figure, which 'reanimates' the pope by another means. ${ }^{118}$ Even Rustici's muscular Mercury for the Medici palace fountain shuns the gold surface of the earlier boy.

${ }^{116}$ C. M. Rosenberg, 'Some New Documents concerning Donatello's Unexecuted Monument to Borso d'Este in Modena', Mitteilungen des Kunsthistorischen Institutes in Florenz, 17, 1973, pp. 149-152. The agreed price of 300 gold florins for labour and materials would seem far too modest for what has sometimes been assumed to be an equestrian statue, (for example, A. Fémelat, 'Donatello, Creator of the Modern Public Equestrian Monument', in Paolozzi Strozzi and M. Bormand (eds. ) as at note 5 above, p. 51 and note 3).

${ }^{117}$ Butterfield, as at note 105 above, chap. 3; For the Mercury see V. Avery, Renaissance and Baroque Bronzes from the Fitzwilliam Museum, Cambridge, London, Gli Ori, 2002, cat. no. 2, and P. Sénéchal, Giovan Francesco Rustici (1475-1554), Paris, Arthéna, 2007, pp. 98-104.

118 Wright, as at note 81 above, chaps. 12 and 13. 
The moment of completely gilded statuary in Florence was emphatically the 1420s, marked by a particular convergence of political, economic and social interests. These interests were, like those liminal bodies we have addressed, either fugitive or in formation. Over the next decades the influence and the coffers of the Parte Guelfa would dwindle as a result of the governmental reforms of the early Medici (post 1434). ${ }^{119}$ Though the Parte presented the removal of their St. Louis of Toulouse to Franciscan S. Croce as an honourable withdrawal from the 'low' company of the marginalised guilds, it was also a withdrawal from political and cultic life. ${ }^{120}$ The florin lost its pre-eminence internationally, while Cosimo and his sons, who did not qualify for effigies, employed other sculptural materials for marking funerary

\footnotetext{
119 In 1458 a Medici balia (special council) placed the Parte Guelfa under the authority of government Councils and Louis of Toulouse's feast day was dropped from the communal calendar, see Zervas, as at note 23 above, pp. 113 and 116.
}

120 Zervas, ibid , p. 113. The cult life of St. Louis of Toulouse at S. Croce had been lively, see D. Norman, Siena and the Angevins, 1300-1350: Art, Diplomacy and Dynastic Ambition, Turnhout, Brepols, 2018, pp. 175-182. 
distinction, notably coloured hard stones and ungilded bronze. ${ }^{121}$ The demand for gilded statuary from Florentine and other craftsmen shifted abroad, with Florence' ally Duke Galeazzo Maria Sforza looking, in the 1470s, among the goldsmiths of Milan for the expertise to make a gilded equestrian monument to his father. In this he was no doubt inspired as much by the antique 'Regisole' in Pavia and the mordant-gilded statue of Niccolo III d'Este as by Florentine example. ${ }^{122}$ The unsettling power of the gilded body in later fifteenth-century Florence might well have been tempered by the cumulative patina of dirt settling on those works, which have been discuss here in their pristine taste. Certainly, when in the mid 1490s and after Medici expulsion, ancient civic sculpture was imagined in painting, gold is contained within the margins: Botticelli's heroic Story of Lucretia panel and moral allegory The Calumny of Apelles, represent gilding only in the architectural sculpture and historiated reliefs, like those of the Baptistery doors. ${ }^{123}$ The exemplary statuary is

${ }^{121}$ For the decline of the florin see Goldthwaite, as at note 37 above, pp, 55-57; Spufford, as at note 20 above, p. 356 for the collapse of several Florentine banks in the 1460 s during the nadir of the precious metal supply. W. Stedman Sheard, 'Verrocchio's Medici Tombs and the Language of Materials; with a Postscript on his Legacy in Venice', in S. C. Bule, A. P. Darr, and F. Superbi Gioffredi, Verrocchio and Late Quattrocento Italian Sculpture, Florence, Le Lettere, 1992, pp. 63-90; Butterfield, as at note 105 above, chap 2.

${ }^{122}$ C. M. Rosenberg, The Este Monuments and Urban Development in Renaissance Ferrara, Cambridge, Cambridge University Press, 1997, p. 76 for the painter Michele Ongaro being paid for the gilding. 
white. This, the viewer can infer, is the unadorned, stable body in the virtuous marble of the new Republic, readied against the threat of gilded tyranny.

${ }^{123}$ For the subjects of the statuary and the reliefs of the Calumny see esp. A. Dressen, 'From Dante to Landino: Botticelli's Calumny of Apelles and its Sources', Mitteilungen des Kunsthistorischen Institutes in Florenz, 59, 2017, pp. 324-339. For the Story of Lucretia see N. Silver, Botticelli: Heroines and Heroes, exh. cat. Isabella Stewart Gardner Museum, Boston, Paul Holberton Publishing, 2019, pp. 